\section{Authors}

Paulo Roberto Alcalde ${ }^{1}$

Gianna Mastroianni Kirsztajn ${ }^{1}$

${ }^{1}$ Universidade Federal de São Paulo, Division of Nephrology, São Paulo, SP, Brasil.
Submitted on: 08/25/2017.

Approved on: 11/29/2017.

\section{Correspondence to:}

Gianna Mastroianni Kirsztajn. E-mail: gm.kirsztajn@unifesp.br

DOI: 10.1590/2175-8239-JBN-3918

\title{
Expenses of the Brazilian Public Healthcare System with chronic kidney disease
}

\author{
Gastos do Sistema Único de Saúde brasileiro com doença renal \\ crônica
}

\section{Abstract}

Introduction: The prevalence of chronic kidney disease (CKD) is increasing worldwide, with costs that can be impeditive. Objective: To establish the expenses of the Brazilian Public Healthcare System (SUS), with hospitalizations due to CKD and related diseases; evaluating expenses with renal replacement therapy (RRT). Methods: We have assessed the values paid by the SUS in the triennium 2013-2015, for estimating annual expenses with CKD treatment and hospitalization, associated diseases, and exams. Results: There was an increase in hospitalization by all causes in Brazil during this triennium. CKD and associated diseases corresponded to $1.82 \%$ and $5.79 \%$ of hospitalizations due to all causes in Brazil, and $2.87 \%$ and $10.10 \%$ of all expenses, respectively. Kidney grafts from deceased donors corresponded to $76 \%$ of hospitalizations and $80 \%$ of expenses with transplantation. There was a decrease in transplantation from living donors. There was an increase in the number of exams of $11.94 \%$ and of $10.95 \%$ in the expenses. There was a decrease in the number of procedures and expenses in intermittent peritoneal dialysis (IPD) and related procedures; but other procedures increased. Hemodialysis (3 weekly sessions) corresponded to $95.96 \%$ of procedures and $96.07 \%$ of expenses with dialysis in general. Conclusion: Renal diseases and some of the main related diseases corresponded to $12.97 \%$ of the expenses in the triennium 2013-2015, and RRT to more than 5\% of the SUS expenses with medium and high complexity healthcare. Such high expenses determine great concerns on the future maintenance of treatment for stage-5 CKD in Brazil and countries in similar or worse conditions of development.

Keywords: Renal Insufficiency, Chronic; Health Care; Cost Control; Health Systems; Hospitalization; Database.

\section{Resumo}

Introdução: A prevalência de doença renal crônica (DRC) está aumentando em todo o mundo, com custos que podem ser impeditivos. Objetivo: Estabelecer os gastos do Sistema Único de Saúde (SUS) com internação hospitalar por DRC e doenças relacionadas; avaliar os gastos com terapia renal substitutiva (TRS). Métodos: Avaliamos os valores pagos pelo SUS no triênio 2013-2015, para estimar as despesas anuais com tratamento da DRC e internação por DRC, doenças associadas e exames. Resultados: Houve aumento da hospitalização por todas as causas no Brasil neste triênio. A DRC e as doenças associadas corresponderam a $1,82 \%$ e $5,79 \%$ das internações hospitalares por todas as causas no Brasil, e 2,87\% e 10,10\% de todas as despesas, respectivamente. Os enxertos renais com doadores falecidos corresponderam a $76 \%$ das internações e $80 \%$ das despesas com o transplante. Houve uma diminuição em transplantes de doadores vivos. Houve um aumento no número de exames de $11,94 \%$ e em despesas de 10,95\%. Houve uma diminuição no número de procedimentos e despesas em diálise peritoneal intermitente (IPD) e procedimentos relacionados; mas outros procedimentos aumentaram. A hemodiálise (3 sessões semanais) correspondeu a $95,96 \%$ dos procedimentos e $96,07 \%$ dos gastos com diálise em geral. Conclusão: As doenças renais e algumas das principais doenças relacionadas corresponderam a $12,97 \%$ das despesas no triênio 2013-2015 e a TRS a mais de 5\% das despesas do SUS com atenção à saúde de média e alta complexidade. Tais gastos elevados determinam grandes preocupações quanto à manutenção futura do tratamento da DRC estágio 5 no Brasil e em países em condições de desenvolvimento semelhantes ou piores.

Palavras-chave: Insuficiência Renal Crônica; Atenção à Saúde; Controle de Custos; Sistemas de Saúde; Hospitalização; Base de Dados. 


\section{INTRODUCTION}

Since the enactment of the Federal Constitution, in 1988, the Unified Healthcare System (SUS) was created, making access to healthcare free for the entire Brazilian population. Its final deployment took place in 1990, by Law $n^{\circ} 8,080$, through which the healthcare system in Brazil was unified, with decentralized management; therefore, it was no longer managed exclusively by the Union, but also by States and Municipalities. ${ }^{1}$

With the objective of providing information for the democratization of healthcare and the improvement of its management, the DATASUS was created in 2011, the SUS Department of Information Technology, essential for the decentralization of healthcare activities and the feasibility of social control over the use of the available resources. ${ }^{2}$

The DATASUS website provides access to a variety of healthcare-related information available in the SUS Outpatient Information System (SIA/SUS) and in the SUS Hospital Information System (SIH/SUS).

SUS plays an important role in the care of patients with chronic kidney disease (CKD), and it is currently responsible for $90 \%$ of the treatment of patients undergoing renal replacement therapy (RRT), which includes dialysis (hemodialysis and peritoneal dialysis) and renal transplantation.

We performed the present study in order to better measure what CKD expenditures represent in our country. It is known that, at all stages, and especially in the terminal stages, CKD represents a considerable burden on the healthcare system, so it is necessary to understand it in a more comprehensive way, to properly define the public policies to be adopted in this area.

\section{Material and Methods}

This is a descriptive study that used information from the Ministry of Health Data System (DATASUS) (www.datasus.saude.gov.br), through access to information in the TABNET, HealthCare in the groups: Hospital Production, SIH/SUS and SIA/SUS and SIGTAP, as follows: hospital production (expenses and hospitalizations related to kidney transplantation and simultaneous pancreas and kidney), SIH / SUS (expenses and hospitalizations related to CKD and diseases associated with CKD) and SIA/SUS (expenses for examinations for identification, follow-up and treatment of CKD, dialysis and procedures) and SIGTAP (expenses with healthcare professionals' fees and examinations used in different stages of CKD).

The values paid by the SUS during the 2013-2015 triennium were evaluated as a basis for estimating annual expenses with CKD treatments in Brazil and hospitalizations for CKD and CKD-related diseases, as well as examinations related to its diagnosis and treatment. The examinations included in this study were based on the Clinical Guidelines for the care of patients with CKD in the SUS at different stages of the disease. We categorize the treatment of renal disease in therapies administered during hospitalization for diagnosis and follow-up, dialysis and renal transplantation.

The following are among the main causes of CKD: diabetes mellitus (DM), systemic arterial hypertension (SAH) and cardiovascular diseases, acute myocardial infarction (AMI) and related conditions, as well as cerebrovascular accidents (Stroke) and related conditions.

CKD is currently defined as the presence of renal damage and/or reduction of the glomerular filtration rate (GFR less than $60 \mathrm{~mL} / \mathrm{min} / 1.73 \mathrm{~m}^{2}$ body surface area) for three months or more, regardless of the cause. ${ }^{3}$ The current definition encompasses patients without glomerular filtration deficits, but we will refer in this article to "renal failure", considering how the patients' diagnoses were actually recorded in the DATASUS in the study period, not the current definition.

The term "procedures" used in Table 1 of the results refers to: 1 ) the training of patients undergoing peritoneal dialysis - APD/CAPD (9 days); 2) the implantation of catheters: catheter for subclavian of double lumen for hemodialysis; long-term catheter for hemodialysis; dual lumen catheter implant for hemodialysis; long-term catheter implantation for hemodialysis; 3) the manufacture of arteriovenous fistula for hemodialysis; 4) maintenance and home monitoring of patients submitted to APD/CAPD; 5) the manufacture of arteriovenous fistula with polytetrafluoroethylene (PTFE) grafting; 6) the creation of arteriovenous fistula with autologous graft; 7) the Tenckhoff catheter implant or similar to APD/CAPD; 8) Tenckhoff catheter implant or similar for IPD; 9) intervention in arteriovenous fistula; 10) arteriovenous fistula ligation; 11) withdrawal of Tenckhoff/ long-term similar catheter. 


\begin{tabular}{|c|c|c|c|c|}
\hline TABLE 1 & $\begin{array}{l}\text { EXPENDITURES (R\$) AND } \\
\text { PROCEDURES IN THE } 2013\end{array}$ & $\begin{array}{l}\text { HEMODIALYSIS AND P } \\
\text { NIUM }\end{array}$ & NEAL DIALYSIS SESSIC & AND THEIR \\
\hline & & 2013 & 2014 & 2015 \\
\hline IPD-1 & $\mathrm{N}$ & 508 & 478 & 263 \\
\hline II & $\mathrm{R} \$$ & $61,843.92$ & $58,191.72$ & $32,017.62$ \\
\hline -2 & $\mathrm{N}$ & 4.443 & 3.039 & 2.668 \\
\hline $110-2$ & $\mathrm{R} \$$ & $539,868.93$ & $369,268.89$ & $324,188.68$ \\
\hline Hems-1 & $\mathrm{N}$ & 167.912 & 168.637 & 181.771 \\
\hline 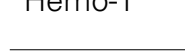 & $\mathrm{R} \$$ & $29,855,413.81$ & $30,191,082.11$ & $32,542,462.13$ \\
\hline Hemo-3 & $\mathrm{N}$ & 12.295 .381 & 12.809 .370 & 12.876 .765 \\
\hline пепло-з & $R \$$ & $2,184,429,080.70$ & $2,293,261,511.10$ & $2,305,330,675.53$ \\
\hline Hemo HIV & $\mathrm{N}$ & 96.743 & 104.476 & 446.295 \\
\hline Hep 3 & $\mathrm{R} \$$ & $25,482,396.59$ & $27,728,975.16$ & $118,451,155.95$ \\
\hline Hemo HIV & $N$ & 1.587 & 1.741 & 6.025 \\
\hline HepExcep & $\mathrm{R} \$$ & $418,349.03$ & $462,078.81$ & $1,599,095.25$ \\
\hline HemoPed & $\mathrm{N}$ & & 21.605 & 24.409 \\
\hline & $\mathrm{R} \$$ & & $7,645,577.40$ & $8,637,856.92$ \\
\hline Proced & $\mathrm{N}$ & 246.548 & 254.096 & 266.378 \\
\hline rioced & $\mathrm{R} \$$ & $32,962,130.65$ & $69,473,964.41$ & $72,983,181.98$ \\
\hline Total & $N$ & 12.813 .122 & 13.363 .442 & 13.804 .574 \\
\hline & $R \$$ & $2,273,749,083.63$ & $2,429,190,649.60$ & $2,539,900,634.06$ \\
\hline
\end{tabular}

IPD-1: Intermittent peritoneal dialysis - IPD (maximum 1 session per week); IPD-2: Intermittent peritoneal dialysis - IPD (maximum 2 sessions per week); Hemo-1: hemodialysis (maximum 1 session per week - exception); Hemo-3: hemodialysis (maximum 3 sessions per week); Hemo HIV Hep 3: hemodialysis in patient with positive serology for HIV, e/or hepatitis B, and/or hepatitis C (maximum 3 sessions); Hemo HIV HepExcep: hemodialysis in patients with positive serology for HIV, and/or hepatitis B, and/or hepatitis C (exceptional); HemoPed: pediatric hemodialysis (maximum 4 sessions per week); Proced: procedures.

The statistical analysis of all the information collected in this study was made in a descriptive way, by the calculation of some summary measures, such as mean, standard deviation and relative frequency (percentage).

\section{RESULTS}

Regarding the expenses with hemodialysis, peritoneal dialysis and related procedures, a decrease in the number of cases and in the expenditures with intermittent peritoneal dialysis (IPD), IPD-1 (Table 1) was observed during the triennium 2013-2015 (Table 1). $48.23 \%)$ and IPD-2 (39.95\%); all other procedures had an increase. Increases with procedures and expenses with hemodialysis for treatment of patients with HIV and/or hepatitis B and/or C (Hemo HIV Hep3), which were $361.32 \%$ and $364.84 \%$, and Hemo HIV Hep in exceptional situation (Excep), of $279.65 \%$ and $282.24 \%$, respectively.

Standard hemodialysis with three weekly sessions corresponded to $95.96 \%$ of the procedures and $96.07 \%$ of the expenditures.
Data on hospitalization costs for all causes in Brazil for CKD and for CKD-associated diseases can be seen in Tables 2 and 3.

Regarding hospitalization expenditures for kidney transplants performed in Brazil via SUS, during the triennium 2013-2015, most hospitalizations were for grafts from deceased donors, which corresponded to $76 \%$ of admissions and $80 \%$ of hospitalization expenditures (Table 4).

Regarding the expenses with examinations for identification and treatment of CKD in the 20132015 triennium, there was an increase of $11.94 \%$ in the number of exams and $10.95 \%$ in the expenses. Both the number of 24-hour proteinuria tests and its related expenses increased by $32.59 \%$. Renal biopsies had a $16.95 \%$ decrease in the number of procedures and expenditures, as can be seen in Table 5 . Type I urine represented $35.53 \%$ of the exams and $47.51 \%$ of the expenditures, followed by serum creatinine $(29.72 \%$ and $19.87 \%)$ and urea $(25.55 \%$ and $17.08 \%)$, respectively. 


\begin{tabular}{|c|c|c|c|c|}
\hline $\begin{array}{l}\text { TOTAL NUMBEF } \\
\text { BRAZIL IN THE }\end{array}$ & $\begin{array}{l}\text { TALIZ } \\
\mid 5 \text { TRI }\end{array}$ & AND EXPENDITURES ( & FOR ALL CAUSES AN & KIDNEY DISEASES IN \\
\hline Diseases/Year & & 2013 & 2014 & 2015 \\
\hline All сансес & $\mathrm{N}$ & $11,197,160$ & $11,320,287$ & $11,372,044$ \\
\hline All causes & $\mathrm{R} \$$ & $12,698,359,917.70$ & $13,370,407,625.66$ & $13,785,610,945.46$ \\
\hline$\triangle N G / P P G N$ & N & 5,714 & 5,712 & 5,395 \\
\hline AINSIRTIRTIV & $\mathrm{R} \$$ & $2,738,641.26$ & $2,897,907.90$ & $2,741,600.02$ \\
\hline Othor alomorular diconco & $\mathrm{N}$ & 12,779 & 12,004 & 11,203 \\
\hline Uther glomerular diseases & $\mathrm{R} \$$ & $6,912,120.44$ & $6,898,722.23$ & $7,154,407.01$ \\
\hline Tubulointerstitial diseases & $\mathrm{N}$ & 92,629 & 90,069 & 86,450 \\
\hline & $\mathrm{R} \$$ & $34,943,288.81$ & $36,530,932.07$ & $36,491,157.79$ \\
\hline$C K F$ & N & 95,186 & 98,220 & 102,110 \\
\hline 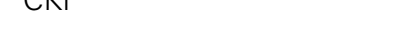 & $\mathrm{R} \$$ & $305,589,824.67$ & $343,252,964.84$ & $357,376,199.04$ \\
\hline
\end{tabular}

ANS, acute nephritic syndrome; RPGN, rapidly progressive glomerulonephritis; CKF, chronic kidney failure.

\begin{tabular}{|c|c|c|c|c|c|}
\hline TABLE 3 & \multicolumn{5}{|c|}{$\begin{array}{l}\text { TOTAL NUMBER OF HOSPITALIZATIONS (N) AND EXPENDITURES (R\$) FOR ALL CAUSES AND FOR SYSTEMIC ARTERIAL } \\
\text { HYPERTENSION (SAH), CARDIOVASCULAR AND CEREBROVASCULAR DISEASES, AND DIABETES (DM) IN BRAZIL IN } \\
\text { THE 2013-2015 TRIENNIUM }\end{array}$} \\
\hline \multicolumn{3}{|c|}{ Diseases/Year } & 2013 & 2014 & 2015 \\
\hline \multirow{2}{*}{\multicolumn{2}{|c|}{ All causes }} & $\mathrm{N}$ & $11,197,160$ & $11,320,287$ & $11,372,044$ \\
\hline & & $\mathrm{R} \$$ & $12,698,359,917.70$ & $13,370,407,625.66$ & $13,785,610,945.46$ \\
\hline \multirow{2}{*}{\multicolumn{2}{|c|}{ Primary SAH }} & $\mathrm{N}$ & 79,256 & 75,419 & 67,889 \\
\hline & & $\mathrm{R} \$$ & $26,415,567.89$ & $26,720,485.44$ & $24,987,013.86$ \\
\hline \multirow{2}{*}{\multicolumn{2}{|c|}{ Other hypertensive diseases }} & $\mathrm{N}$ & 26,924 & 26,803 & 24,940 \\
\hline & & $\mathrm{R} \$$ & $15,531,169.47$ & $13,604,391.52$ & $14,035,285.21$ \\
\hline \multirow{2}{*}{\multicolumn{2}{|c|}{ Acute myocardial infarction }} & $\mathrm{N}$ & 86,559 & 94,399 & 101,208 \\
\hline & & $\mathrm{R} \$$ & $286,910,053.12$ & $332,383,877.36$ & $365,200,613.59$ \\
\hline \multirow{2}{*}{\multicolumn{2}{|c|}{ Other ischemic cardiac diseases }} & $\mathrm{N}$ & 156,636 & 159,435 & 152,869 \\
\hline & & $\mathrm{R} \$$ & $689,163,626.60$ & $697,415,603.15$ & $680,017,034.99$ \\
\hline \multirow{2}{*}{\multicolumn{2}{|c|}{$\begin{array}{l}\text { Ischemic or hemorrhagic } \\
\text { cerebrovascular accident }\end{array}$}} & $\mathrm{N}$ & 133,822 & 141,909 & 145,970 \\
\hline & & $\mathrm{R} \$$ & $156,146,579.87$ & $172,055,725.92$ & $181,525,244.48$ \\
\hline \multirow{2}{*}{\multicolumn{2}{|c|}{$\begin{array}{l}\text { Transitory ischemic accident and } \\
\text { correlated syndromes }\end{array}$}} & $\mathrm{N}$ & 25,968 & 21,119 & 21,297 \\
\hline & & $\mathrm{R} \$$ & $26,661,498.35$ & $21,684,582.62$ & $22,598,156.11$ \\
\hline \multirow{2}{*}{\multicolumn{2}{|c|}{ DM }} & $\mathrm{N}$ & 140,873 & 139,819 & 138,217 \\
\hline & & $\mathrm{R} \$$ & $88,401,913.93$ & $89,667,747.68$ & $92,230,156.60$ \\
\hline
\end{tabular}

\section{Discussion}

Considering the increase in CKD prevalence in the present day, one of the reasons for greater concern is that it is not due to the increase in the number of inherited renal diseases; but rather, systemic diseases that secondarily injure the kidneys, such as atherosclerosis.5, determine it.

Another factor considered relevant to the increase in terminal stage CKD in the world, besides the exponential growth of type 2 diabetes, is the aging of the population in developed countries. The incidence of the disease in the elderly (here considered individuals over 65 years of age) in the UK is above $350 \mathrm{pmh}^{6}$ and in the United States it is 1200 pmh. $^{7}$

The prevalence of CKD in the community has been largely underestimated in the past; but recent research and population studies have revealed the prevalence of CKD in the general population. In the United States, approximately $11 \%$ of the population is estimated to have CKD at some stage of evolution, according to the results of the Third National Health 


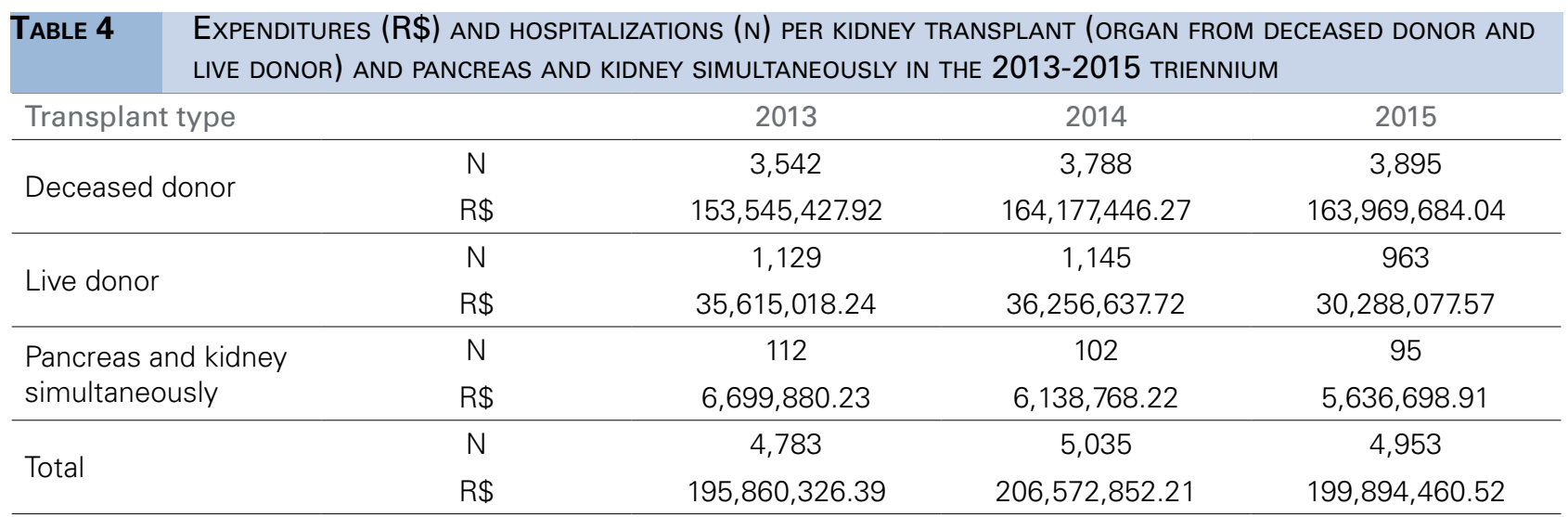

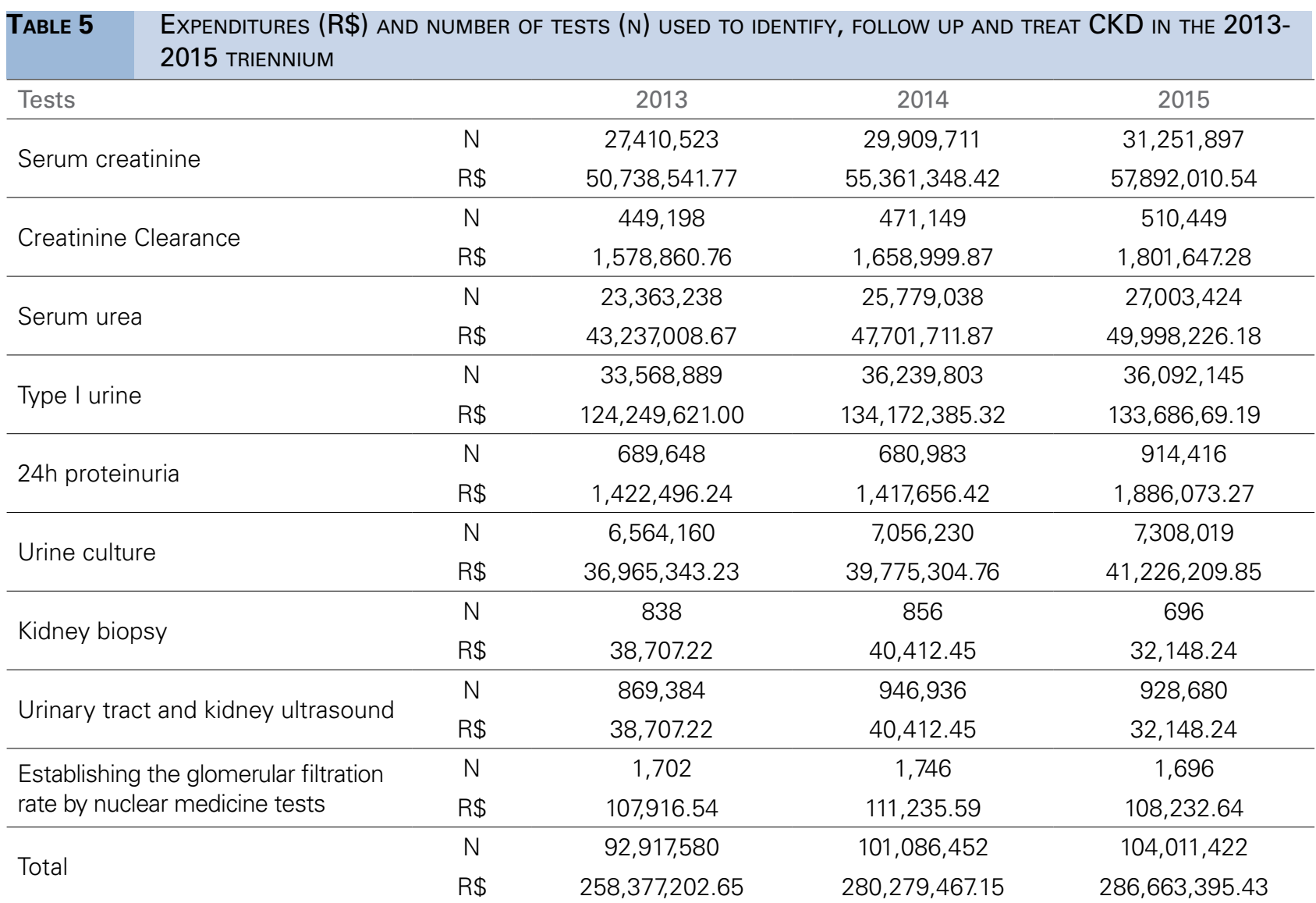

and Nutrition Examination Survey. ${ }^{8}$ About $73 \%$ of these individuals have a glomerular filtration rate of less than $60 \mathrm{~mL} / \mathrm{min} .{ }^{9}$ Even more serious is that most of these individuals fail to develop terminal CKD because they die of cardiovascular complications before progressing to the terminal stage of CKD.

In fact, it is known that patients with CKD, when compared to the general population, have a higher prevalence of cardiovascular diseases, including coronary, cerebrovascular, peripheral vascular and heart failure. In addition, the development of cardiovascular disease has been shown to be early in the course of CKD, representing the leading cause of death in the early stages of $\mathrm{CKD}^{10}$, or at any stage, for patients in both conservative and renal replacement therapy, ${ }^{11}$ which is attributed to the high prevalence of classic CVD risk factors in patients with CKD, which are associated with risk factors related to CKD itself, and which worsen as the glomerular filtration rate decreases. ${ }^{12}$ 
The prevalence of CKD has been increasing in most countries. ${ }^{13}$ In the present study, it was possible to see a certain trend of growth in hospitalizations and expenditures, considering all the causes of diseases occurring in Brazil during 2013 to 2015, among which there were hospitalizations for renal failure. On the other hand, hospitalizations for renal diseases "without renal failure" went down.

During the triennium, acute myocardial infarction and unspecified (hemorrhagic or ischemic) stroke had an increase in hospitalizations and expenditures, and DM only increased expenditures. The other morbidities associated with CKD presented a decrease in hospital admissions and expenses. In Brazil, cardiovascular diseases have been known to increase, which are the cause of hospitalization, morbidity and mortality, a profile that is closer to that of the industrialized countries, and not to the underdeveloped ones, in which infectious-contagious diseases predominate. The pattern observed in our study reflects precisely the change that a country like ours, in development, is suffering because of the significant increase in the number of patients with chronic diseases, especially cardiovascular disease and DM. It is worth noting that CKD has appeared more recently as a major public health concern, as already commented.

In the current study, kidney diseases (chronic renal failure, glomerular and tubulointerstitial diseases), and some of the major associated diseases (DM, SAH and other hypertensive diseases, stroke and related diseases) accounted for $7.61 \%$ of hospital admissions and $12.97 \%$ of total hospital admissions and expenses in Brazil, considering all causes. These numbers account for a large percentage of national healthcare expenditures and are only likely to increase, even if only one-offs are taken into account, such as changing the country's development profile (cited above) and population aging. ${ }^{14}$ It draws attention for being an expressive expense for only four diseases. However, it should be emphasized that chronic diseases are important because of the frequency that people currently develop them. It should also be borne in mind that part of the patients hospitalized due to DM, primary hypertension and other hypertensive diseases, AMI and related diseases, stroke and related diseases, among others, may also have CKD at different stages of evolution, but this diagnosis was not described as the one being responsible for the hospitalization.
Regarding renal replacement therapies, we observed that kidney transplantation with a living donor organ and simultaneous transplantation of pancreas and kidney had a decrease in hospitalizations and expenditures over the 2013-2015 triennium. On the other hand, kidney transplantation with a deceased donor organ showed a continuous increase in both instances. This finding is not surprising; the tendency to increase transplants using deceased donors has been outlining for some years, and it is currently a reality in our country. Organ donation has been encouraged in Brazil through campaigns that stimulate and encourage persons to reveal to family members their desire to be an organ donor. In fact, according to the Brazilian Registry of Transplantation (ABTO), $78.9 \%$ of kidney transplants in Brazil in 2015 were performed with organs from deceased donors; thus, only a small portion depended on living donors. The ABTO data also showed that, in the last ten years, kidney transplants with deceased organ donors had an increase of $170.95 \%$, with a $33 \%$ decrease in kidney transplantation with live donor, and simultaneous $14.91 \%$ pancreas and kidney transplantation. ${ }^{15}$

Intermittent peritoneal dialysis (one and two sessions per week) experienced a decrease in procedures and expenditures; the other dialysis procedures increased, with emphasis on the growth of procedures and expenses with hemodialysis in patients with positive serology for HIV and/or hepatitis B and/or hepatitis $\mathrm{C}$ (maximum 3 sessions), and hemodialysis in patients with positive serology for HIV, and/or hepatitis $\mathrm{B}$, and/or hepatitis C (exceptionality). The reason for increased spending on hemodialysis sessions for HIVpositive patients and/or those with viral hepatitis was unclear, but there are some possibilities, such as the increase in the number of patients with these conditions who survived the initial phase of the disease due to the current therapeutic resources and have managed to reach the dialysis, or even the increase in the number of cases of these diseases, or only in the number of diagnoses, previously not performed, which is more likely.

It is also worth noting that in Brazil, in July 2014, $91.4 \%$ of patients on chronic dialysis were treated by hemodialysis, and $8.6 \%$ by peritoneal dialysis, and automated peritoneal dialysis was the predominant modality. The percentage of patients undergoing maintenance hemodialysis has remained stable, 
and there is a trend towards an overall increase in the number of dialysis patients, incidence rates and treatment prevalence, particularly considering the last four years. It is important to say that the payment for these procedures in Brazil is done predominantly by the SUS. ${ }^{5}$

A study by Menezes et al. ${ }^{15}$ explored the scenario of hemodialysis treatment paid by the SUS in Brazil, emphasizing that almost half of the country's hemodialysis expenditures were concentrated in São Paulo, Rio de Janeiro and Minas Gerais. This is another very important aspect, the inequality of treatment performed, which is independent of the population of each region, also documented by Sesso et al. ${ }^{5}$

In order to have an idea of the extent of RRT expenditures in Brazil compared to those for various diseases, it is worth recalling some spending figures for the year 2015. Thus, for all-cause hospitalizations we spent 13.8 billion Reals and, according to our survey, more than 2 billion with RRT (about 200 million with renal transplantation and 2 billion with dialysis), not included here there are approximately 357 million spent on patients with kidney failure. As a comparison, hospitalizations for acute myocardial infarction and related diseases accounted for about 1 billion reals in the same year, or less than half of that for RRT in Brazil.

Considering what was disclosed for the total SUS spending in 2015, with the medium and high complexity healthcare procedures in the Brazilian population, that is, 40 billion reals, it is worth noting that the expenses with RRT (i.e. only with CKD treatment in stage 5) accounted for more than 2 billion Reals, and 2 billion correspond to $5 \%$ of the SUS costs with medium and high complexity treatments, consumed with part of the management of a single disease, the incidence of which is increasing.

It must be said that a study based primarily on the number and expenditures on hospitalizations motivated by selected diagnoses, such as ours, has its limitations. The information available is true, but it is known that certain data or diagnoses may be lacking. Still, it is generally considered as having good reliability. In fact, several cost studies have been carried out using these databases, in order to evaluate the economic impact of some causes of hospital admissions in our country. ${ }^{16}$

In Brazil, hospital statistics are better systematized than outpatient statistics, ${ }^{17}$ therefore hospitalization expenditure surveys are used as a way of measuring healthcare costs, as we did in the present study.

When considering current trends in the prevalence of CKD, RRT will probably be difficult to maintain in a time not too distant, even for industrialized countries, ${ }^{18}$ hence the importance of having expenditures studies in this area, seeking to alert about the problem and the need to look for alternatives, such as early prevention, diagnosis and treatment of CKD.

\section{Acknowledgement}

The authors are grateful for the support given by the National Council for Scientific and Technological Development (CNPq) for this study.

\section{References}

1. Portal Brasil - SUS democratiza acesso do cidadão aos serviços de saúde. [acesso 2016 Maio 5]. Disponível em: http://www. brasil.gov.br/saude/2009/11/sus-democratiza-o-acesso-docidadao-aos-servicos-de-saude/sus-democratiza-o-acesso-docidadao-aos-servicos-de-saude/view

2. Portal da Saúde - O DATASUS. [acesso 2016 Jun 6]. Disponível em: http://www2.datasus.gov.br/DATASUS/index.php

3. Levey AS, Eckardt KU, Tsukamoto Y, Levin A, Coresh J, Rossert J, et al. Definition and classification of chronic kidney disease: a position statement from Kidney Disease: Improving Global Outcomes (KDIGO). Kidney Int 2005;67:2089-100.

4. Zimmet P, Alberti KG, Shaw J. Global and societal implications of the diabetes epidemic. Nature 2001;414:782-7.

5. Sesso RC, Lopes AA, Thomé FS, Lugon JR, Martins CT. Brazilian Chronic Dialysis Census 2014. J Bras Nefrol 2016;38:5461.

6. Hamer RA, El Nahas AM. The burden of chronic kidney disease is rising rapidly worldwide. BMJ 2006;332:563-4.

7. Excerpts From the United States Renal Data System 2004 Annual Report: Atlas of End-Stage Renal Disease in the United States. Am J Kidney Dis 2005;45:1-280.

8. Coresh J, Astor BC, Greene T, Eknoyan G, Levey AS. Prevalence of chronic kidney disease and decreased kidney function in the adult US population: Third National Health and Nutrition Examination Survey. Am J Kidney Dis 2003;41:112.

9. Dirks JH, de Zeeuw D, Agarwal SK, Atkins RC, Correa-Rotter R, D'Amico G, et al.; International Society of Nephrology Commission for the Global Advancement of Nephrology Study Group 2004. Prevention of chronic kidney and vascular disease: toward global health equity--the Bellagio 2004 Declaration. Kidney Int 2005;68:S1-6.

10. Canziani MEF. Doenças Cardiovasculares na Doença Renal Crônica. J Bras Nefrol 2004;26:20-1.

11. Bucharles SGE, Varela AM, Barberato SH, Pecoits-Filho R. Assessment and management of cardiovascular disease in patients with chronic kidney disease. J Bras Nefrol 2010;32:120-7.

12. Varela AM, Pecoits Filho RFS. Interactions between cardiovascular disease and chronic kidney disease. J Bras Nefrol 2006;28:22-8.

13. Barsoum RS. End-stage renal disease in the developing world. Artif Organs 2002;26:735-6.

14. Brasil. Instituto Brasileiro de Geografia e Estatística (IBGE). Censo Demográfico 2010. [acesso 2018 Abr 16]. Disponível em: https://ww2.ibge.gov.br/home/estatistica/populacao/censo2010/default.shtm 
15. Registro Brasileiro de Transplantes. Ano XXI, No.3 Jan/Set 2016. Associação Brasileira de Transplante de Órgãos (ABTO). [acesso 2018 Abr 16]. Disponível em: http://www.abto.org.br/ abtov03/default. aspx? $\mathrm{mn}=457 \& \mathrm{c}=900 \& \mathrm{~s}=0$

16. Peixoto SV, Giatti L, Afradique ME, Lima-Costa MF. Custo das internações hospitalares entre idosos brasileiros no âmbito do Sistema Único de Saúde. Epidemiol Serv Saúde 2004;13:23946.
17. Nascimento EMR, Mota E, Costa MCN. Custos das internações de adolescentes em unidades da rede hospitalar integrada ao SUS em Salvador, Bahia. Epidemiol Serv Saúde 2003;12:13745.

18. Lysaght MJ. Maintenance dialysis population dynamics: current trends and long-term implications. J Am Soc Nephrol 2002;13:S37-40. 